\title{
【論【文】
}

\section{防腐・防蟻処理廃木材からのクロム，銅，および ひ素の抽出除去処理に関する基礎的研究}

\author{
貫上 佳 則 ${ }^{*}$-木 元 敦 子 ${ }^{* *}$ - 本 多 淳 裕 ${ }^{* * *}$
}

【要 旨】防腐·防蟻加工が施された木材の多くは，薬剤に CCA と呼ばれるクロム，銅，およびひ素 の化合物を用いたものである。この CCA 処理木材は使用段階では人体や周辺環境に悪影響を及ぼさな いが，廃材として焼却処理された場合，燃焼廃ガスや焼却灰中にこれらの重金属が濃縮され，2次污染 を招く恐れがある。そこで CCA 処理木材をチップ化したのちに，溶媒で木材中の重金属を抽出除去す る方法を提案し，基礎的な処理条件について実験的に検討を加えた。その結果，CCA 処理木材を 20 $\mathrm{mm}$ 以下のチップに破研し, $90 \sim 100^{\circ} \mathrm{C}$ に加熱した $0.25 \sim 1 \mathrm{~N}$ の硫酸で 5 時間処理を行うことによっ て，チップに含まれているクロム，銅，およびひ素の $95 \%$ 以上を抽出できることがわかった。さらに， 処理によって同時に抽出される難分解性とみられる TOC 量も把握できた。

キーワード：CCA 処理木材，抽出処理，抽出率，抽出 TOC 量

\section{1.はじめに}

防腐・防蟻処理木材とは, 白蟻や木材腐朽菌などに対 して長期間保護するために防腐剤で加工した木材を指し， 木造住宅の床下材や建築用材, 電柱, 枕木, 遊具, ベン チなどに用いられてきた。現在では, 生産されている防 腐・防蟻処理木材の $70 \%$ 以上が CCA と呼ばれる水溶 性防腐剤で処理したもの (以下 CCA 処理木材と略す) である。CCA 薬鼡は, 銅 (以下 $\mathrm{Cu}$ と略す), クロム (以下 $\mathrm{Cr}$ と略す), およびひ素（以下 As と略す）各々 の化合物で構成されたものである。1938 年にアメリカ で CCA 薬郕が開発されて以来, CCA 処理木材は世界 60 ヶ国以上の国々で 50 年以上にわたって使用されてお り, 長期間防腐・防蟻効果を高く維持できるだけでなく， 臭いもなく木材の強度・吸湿性・塗装性などにも影響を 及ぼさないことが確認されている。CCA 薬剤は水溶性

原稿受付 1994.3. 15

* 大阪市立大学工学部土木工学科 助手

***杫日コン

*** (賏クリーンジャパンセンター

連絡先：干558 大阪市住吉区杉本 3-3-138 大阪市立大学工学部土木工学科 貫上佳則
であるが，木材に圧入加工して定着させることによって， 木材中のセルロースやリグニンなどと結合して化学的に 安定する。このため, 降雨などによって CCA 処理木材 から薬剤成分が流出したり，CCA 処理木材を手でさ わって薬剤が手に付着したりすることはなく, 周辺環境 にも悪影響を及ぼさないことから，現在では最も優れた あのとして位置づけられ，わが国でも JIS ${ }^{1,2)}$ で規定さ れている。

わが国では CCA 処理木材は 1960 年代から生産され, 現在では年間約 30 万 $\mathrm{m}^{3}$ 生産されている。したがって, $\mathrm{CCA}$ 処理木材は使用当初から既に 30 年近く経過してお り, 順次廃材として排出されていくものと推定される゙。 廃木材は，通常構造材や製紙用原料として再利用される あのああるが, 残りは焼却処理されている。焼却される 廃材の中に CCA で防腐処理された木材が混入している 之, 廃ガス中にAsが混入したり, 焼却灰に高濃度の $\mathrm{Cu}, \mathrm{Cr}$ ，および As が含まれたりして環境污染を引き 起こす恐れがある。このため, バーゼル条約であ CCA 薬剤が対象物に取り上げられており4,，アメリカやイギ リスでは CCA 処理木材の加工や廃棄に対して注意を促 している゙๋。

これらの CCA 防腐木材の処理・処分方法には, (1) 重 金属を補集できる廃ガス処理施設を完備した炉で焼却処 
理し，その焼却灰に重金属の溶出防止策を施したのち埋 立処分する方法，(2) 破砕したのち埋立処分する方法, (3) 溶媒に重金属を抽出させて除去する方法などが考え られる。このうち (1) の方法では, 燃焼廃ガスにAs が 含まれ，その除去技術が必要になる ${ }^{5,6)}$ ばかりでなく，高 濃度の重金属を含む焼却灰を生み出すことになる。また, (2)の方法では, 埋立処分地内で廃木材が腐敗分解し, 長 期にわたって高濃度の有機成分を含む浸出水を発生させ ることになる。また, 廃木材の腐敗分解による $\mathrm{Cu}, \mathrm{Cr}$, およびAs の浸出水への溶出も心配される。これに対し て (3)の方法では, 技術的に不明な点が多いものの, 抽 出条件によってはこれら重金属を木材から確実に除去し, 生じる廃液を防腐処理薬剂として再利用できる可能性を 秘めているものである。

このような背景から，本研究では CCA 処理木材から $\mathrm{Cu}, \mathrm{Cr}$ ，および As を湿式で抽出除去する際の基礎的 な抽出条件に関して実験的に検討を行った。

\section{2. 実験方 法}

\section{1 サンプルの作成とサンプル年の決定方法}

実験には，CCA 薬剂で防腐・防蟻処理を施し， 1 力 月間の薬剂定着を終えたアメリカ産のッガ材を用いた。 通常 CCA 薬剤で防腐・防蟻処理される際には, 薬剤が 木材表面から 1 ～ $2 \mathrm{~cm}$ ほどの深さまでしか浸透しない ため，防腐・防蟻処理された角材の表面約 $1 \mathrm{~cm}$ の部分 をチッパーと 2 軸せん断粉砕機，およびウィレー氏式粉 砕機で処理して，ふるいで所定の粒度にふるい分けたも のをサンプルとし, 四分法で縮分して所定のサンプル量 を取り分けた。実験 1 および 2 では, チップ中 $\mathrm{Cu}, \mathrm{Cr}$, As 量のばらつきの影響を極力避けるため, $1 \mathrm{~mm}$ 以下 のサンプルを用いた。

実験 3 では, サンプルの粒径を 5 段階にわけて実験を おこなったが, 1 回の実験に用いるサンプル量を決める ために, サンプル量と含有率のばらつきとの関係を以下 に示すような簡便法で調べた。まず最初に, 各段階のサ ンプルの全体量の $10 \%$ を塗料でマーキングして充分に 混合した。ここから 4 分法で縮分して代表サンプルを取 り出して全重量を测定し, この代表サンプルからマーキ ングされたチップを選り分けてその重量を測定して全重 量に対する比率を計算した。この操作を繰り返し, サン プル量とマーキングされたチップの割合との関係を粒径 ごとにグラフ化して, 值のばらつき具合から適切なサン プル量を求めた。ただし， $1 \mathrm{~mm}$ 以下の粒径サンプル は, マーキングされたすのを選り分けることが不可能で あるため, 実験 3 では粒径が $1 \mathrm{~mm}$ 以下のサンプルは,
$1 \sim 5 \mathrm{~mm}$ のものと同じサンプル量で実験を行った。

木材チップ中の $\mathrm{Cu}, \mathrm{Cr}$ ， As 量の測定は，チップ径 の大きなものは細かく粉砕したのち JIS-A 9107 の付属 書にしたがって硫酸と過酸化水素水で加熱分解し，この 試験液中の $\mathrm{Cu}, \mathrm{Cr}, \mathrm{As}$ 濃度を ICP 発光分析装置（島 津製作所, ICP- 1000 III）で測定して，含有量の平均檤 と標準偏差, および変動係数を求めた。

\section{2 実験条件}

$\mathrm{CCA}$ 薬剤によって防腐・防嬟処理された廃木材から $\mathrm{Cu}, \mathrm{Cr}, \mathrm{As}$ を除去するための抽出処理法の処理条件に ついて検討するために，3種類の実験を行った。実験 1 は, 抽出処理に適切な溶媒を選定するための回分実験で あり, 実験 2 は抽出処理に適切な溶媒温度を選定するた めの回分実験, 実験 3 は処理に必要な抽出時間と適切な 溶媒濃度を選定するための回分実験である。各実験に よって適切な抽出条件を選定しながら実験を進めていき， 結果として Table 1 に示すような条件で実験を行った。 実験 1 で比較した溶媒は, 無機酸, 有機酸, およびパル プ製造時に用いる蒸解薬剤を参考にして ${ }^{7)}$ Table 2 に示 した 8 種類の溶媒を用いた。比較対象として蒸解薬剤を 取り上げた理由は, $\mathrm{Cu}, \mathrm{Cr}, \mathrm{As}$ が木材中のリグニンや セルロースと結合しているといわれており ${ }^{8)}$, 蒸解薬剤

Table 1 Experimental Conditions

\begin{tabular}{l|c|c|c}
\hline Run No. & 1 & 2 & 3 \\
\hline extractants & $\begin{array}{c}8 \text { kinds } \\
(\text { see Table 2) }\end{array}$ & sulfuric acid & sulfuric acid \\
\hline Chips size (mm) & $<1$ & $<1$ & 5 ranks \\
\hline $\begin{array}{c}\text { Extraction temperature } \\
\left({ }^{\circ} \mathrm{C}\right)\end{array}$ & 120 & $\begin{array}{c}40 \sim 120 \\
(5 \text { ranks) }\end{array}$ & $90 \sim 100$ \\
\hline Extraction time (hr) & 1 & 1 & 7 \\
\hline $\begin{array}{l}\text { Ratio of extractant } \\
\text { to sample (m } / \mathrm{g})\end{array}$ & 20 & 20 & 20 \\
\hline
\end{tabular}

Table 2 Concentration of Each Extractant

\begin{tabular}{l|c}
\hline Extractants & Concentrations \\
\hline $\mathrm{NaOH} \& \mathrm{Na}_{2} \mathrm{~S}^{*}$ & $\begin{array}{c}25.8 \mathrm{~g} \text { of } \mathrm{NaOH} \text { and } 12.6 \mathrm{~g} \text { of } \\
\mathrm{Na}_{2} \mathrm{~S} \text { in } 1 \mathrm{~L} \text { distilled water }\end{array}$ \\
\hline $\mathrm{NaOH}^{*}$ & $25 \mathrm{~g}$ of $\mathrm{NaOH}$ in $1 \mathrm{~L}$ distilled water \\
\hline $\mathrm{CH}_{3} \mathrm{COOH}$ & $0.25 \mathrm{~N}$ \\
\hline $\mathrm{HNO}_{3}$ & $0.25 \mathrm{~N}$ \\
\hline $\mathrm{H}_{2} \mathrm{SO}_{4}$ & $0.25 \mathrm{~N}$ \\
\hline $\mathrm{HC}_{\ell}$ & $0.25 \mathrm{~N}$ \\
\hline $\mathrm{Na}_{2} \mathrm{SO}_{3} \& \mathrm{NaHCO}_{3}^{* *}$ & $120 \mathrm{~g}$ of $\mathrm{Na}_{2} \mathrm{SO}_{3}$ and $20 \mathrm{~g}$ of \\
\hline $\mathrm{Na}_{2} \mathrm{SO}_{3} \& \mathrm{H}_{2} \mathrm{SO}_{3} * *$ & $\mathrm{NaHCO}_{3}$ in $1 \mathrm{~L}$ distilled water \\
\hline
\end{tabular}

${ }^{*}:$ referred to kraft pulping method

** $:$ referred to neutral sulfite pulping method ${ }^{* * *}$ : referred to acidic sulfite pulping method 
は木材中のリグニンを溶解させてセルロースと分離する 働きをすることから, $\mathrm{Cu}, \mathrm{Cr}, \mathrm{As}$ の抽出にあ効果が期 待されたためである。

実験 1 では, 所定量のサンプルを各溶媒とともに容量 $120 \mathrm{~m} \ell$ の耐圧密閉容器に入れ, オートクレーブを用い て $120^{\circ} \mathrm{C}, \quad 1 \mathrm{kgf} / \mathrm{cm}^{2}$ で 1 時間加熱した。溶媒量は, サ ンプルの浸漬程度から判断してサンプル $1 \mathrm{~g}$ あたり 20 cc の溶媒を用いた。実験終了後, 溶液をガラスフィル 夕ー（東洋濾紙, GS-25）で吸引濾過し, 濾液中の $\mathrm{Cu}$, $\mathrm{Cr}$, As の各濃度を ICP 発光分析装置で測定した。また, 抽出処理によって木材成分であるリグニンなどの難分解 性有機成分あ抽出されてくるため, これら難分解性有機 成分量の指標として抽出液の全有機炭素濃度を TOC 計 （島津製作所製，TOC-500）で測定し，木材チップの単 位量あたりの抽出 TOC 量を計算した。さらに, 使用し た 8 種類の溶媒のうち $\mathrm{NaOH}$ と $\mathrm{Na}_{2} \mathrm{~S}$ との混合溶媒, および $\mathrm{NaOH}$ 溶液はアルカリ性であるため, 抽出処理 後に $\mathrm{Cu}$ あるいは $\mathrm{Cr}$ が水酸化物として不溶物を形成し， 濾過操作によって溶媒から分離されてしまって正しい分 析値を示さない恐れがあったので, 滤過操作の前に塩酸 で中和した場合も比較検討した。

実験 2 では, 所定量のサンプルを $0.25 \mathrm{~N}$ の硫酸とと あに容量 $120 \mathrm{m \ell}$ 耐圧密閉容器に入れ, オイルバスを 用いて $40 \sim 100^{\circ} \mathrm{C}$ の温度で 1 時間加熱したのち, 実験 1 と同様にして抽出液中の $\mathrm{Cu}, \mathrm{Cr}, \mathrm{As}$ 濃度を測定し た。

実験 3 では, 各粒径のサンプルと $0.1 \mathrm{~N}, 0.25 \mathrm{~N}$, あ るいは $1 \mathrm{~N}$ の硫酸を容量 $5 \mathrm{~L}$ のガラス容器に入れ, 攪拌 しながらオイルバスによって溶媒温度が $90 \sim 100^{\circ} \mathrm{C} に$ なるよう加温しながら抽出処理を行った。また, 実験 1 および実験 2 と同様に, 抽出容器に加える硫酸液量はサ ンプル量との比が $20 \mathrm{cc} ： 1 \mathrm{~g}$ となるように定めた。抽 出処理は最大 7 時間としてこの間抽出溶媒を経時的に採 水し, ガラスフィルターで吸引滤過したのち濾液中の $\mathrm{Cu}, \mathrm{Cr}, \mathrm{As}$ の各濃度と TOC 濃度を ICP 発光分析装置 と TOC 計で測定した。

\section{3. 実験結果と考察}

\section{1 サンプル量の決定とチップ中の $\mathrm{Cu}, \mathrm{Cr}, \mathrm{As}$ 量}

チップ中の $\mathrm{Cu}, \mathrm{Cr}, \mathrm{As}$ 量のばらつきを調べるため に行った簡便法の結果を Fig. 1 に示す。サンプル量を 増やすにつれてマーキングされたチップの割合のばらつ きが小さくなる傾向がみられるが，一定值以上にサンプ ル量を増やしてもばらつきはほとんど変わらないことが わかる。実験上の便宜を考慮して, 実験 3 で用いる各径
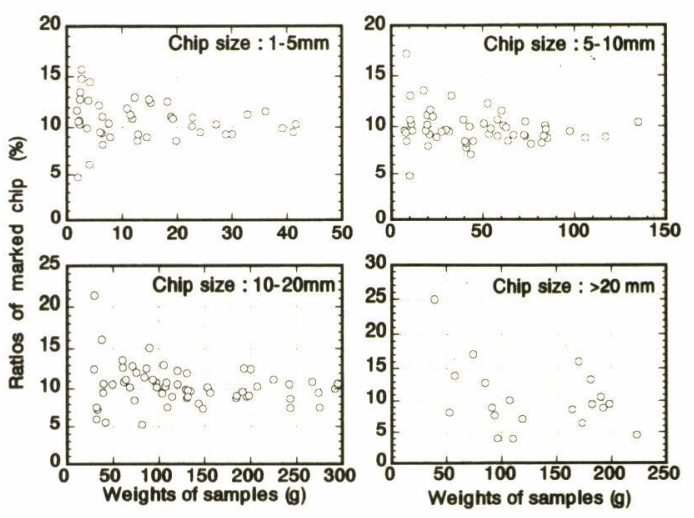

Fig. 1 Relationships between Weight of Samples and Ratios of Marked Chip

Table $3 \mathrm{Cr}, \mathrm{Cu}$, and As Contents in Sample

\begin{tabular}{c|c|c|c|c}
\hline Chips size (mm) & Atom & Ave. (mg/g) & S. D. (mg/g) & C. V. (\%) \\
\hline \multirow{4}{*}{$<1$} & $\mathrm{Cr}$ & 1.47 & 0.0172 & 1.17 \\
\cline { 2 - 5 } & $\mathrm{Cu}$ & 0.978 & 0.00882 & 0.902 \\
\cline { 2 - 5 } & $\mathrm{As}$ & 1.81 & 0.0289 & 1.60 \\
\hline \multirow{4}{*}{$1-5$} & $\mathrm{Cr}$ & 1.50 & 0.0272 & 1.81 \\
\cline { 2 - 5 } & $\mathrm{Cu}$ & 0.970 & 0.0195 & 2.01 \\
\cline { 2 - 5 } & $\mathrm{As}$ & 1.75 & 0.0335 & 1.91 \\
\hline \multirow{5}{*}{$5-10$} & $\mathrm{Cr}$ & 1.39 & 0.0675 & 4.85 \\
\cline { 2 - 5 } & $\mathrm{Cu}$ & 0.915 & 0.0377 & 4.12 \\
\cline { 2 - 5 } & $\mathrm{As}$ & 1.66 & 0.0549 & 3.31 \\
\hline \multirow{5}{*}{$10-20$} & $\mathrm{Cr}$ & 1.21 & 0.159 & 13.2 \\
\cline { 2 - 5 } & $\mathrm{Cu}$ & 0.857 & 0.0981 & 11.4 \\
\cline { 2 - 5 } & $\mathrm{As}$ & 1.56 & 0.162 & 10.3 \\
\hline \multirow{5}{*}{$>20$} & $\mathrm{Cr}$ & 1.14 & 0.158 & 13.9 \\
\cline { 2 - 5 } & $\mathrm{Cu}$ & 0.781 & 0.0999 & 12.8 \\
\cline { 2 - 5 } & $\mathrm{As}$ & 1.48 & 0.179 & 12.1 \\
\hline
\end{tabular}

のサンプル量は, $1 \mathrm{~mm}$ 以下のものと $1 \sim 5 \mathrm{~mm}$ のも のはそれぞれ $50 \mathrm{~g}$ ，その他は $100 \mathrm{~g}$ とした。また，この ようにして量を決めたサンプル中の $\mathrm{Cu}, \mathrm{Cr}, \mathrm{As}$ 含有 量の分析結果をTable 3 に示す。粒径が小さい場合は 変動係数が数\%であるが, $10 \mathrm{~mm}$ 以上になると变動係 数が $10 \%$ 以上の大きな值になって含有量の值が大きく ばらついていることがわかる。

\section{2 溶媒選定のための回分実験（実験 1 ）}

Fig. 2 に, 各々の溶媒を用いた場合の木材チップか らの Cu, $\mathrm{Cr}, \mathrm{As}$ の抽出率と, 単位チップあたりの TOC 抽出量を示す。図中の抽出率とは, 溶媒中の $\mathrm{Cu}$, Cr, As 量を抽出前の含有量で除した値であり, 抽出 TOC 量は溶媒中の TOC 量を試料量で除した値である。 この中で抽出 TOC 量が測定されていないものがあるが, 

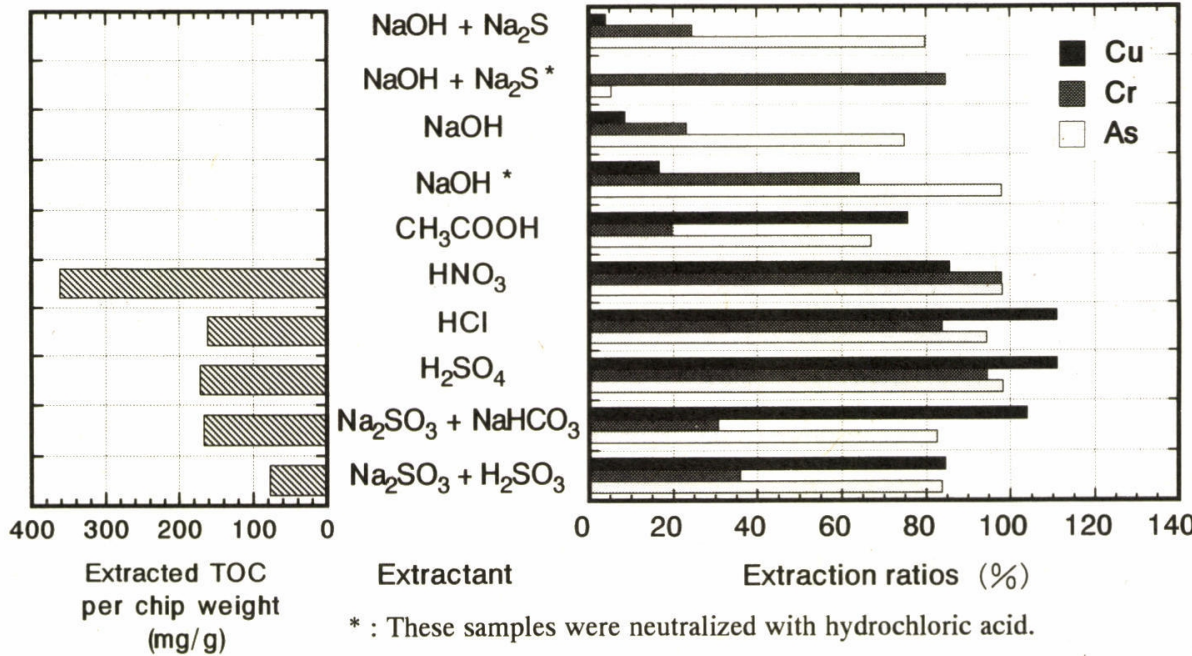

Fig. 2 Extracted TOC and Extraction Ratio of Each Case

TOC 計による分析が不可能であったか, 分析值自身無 意味であるため測定しなかったものである。また，各々 の抽出率の值の中には $100 \%$ を越えるむのがあるが，こ れはサンプル中の $\mathrm{Cu}, \mathrm{Cr}, \mathrm{As}$ 含有量のばらつき，木 材チップの採取時の誤差, 溶媒採水時の誤差, 分析時の サンプル調整の誤差, ICP 発光分析装置による分析誤差 などによるあのであると考えられる。

さらに, アルカリ性である $\mathrm{NaOH}$ 溶液を用いた場合 は，溶媒を滤過する前に塩酸で中和することによって $\mathrm{Cu}, \mathrm{Cr}, \mathrm{As}$ いずれも抽出率が高くなることがわかる。 しかし，アルカリ性である $\mathrm{NaOH}$ と $\mathrm{Na}_{2} \mathrm{~S}$ との混合溶 媒の場合は, $\mathrm{Cr}$ の抽出率は高くなったものの, $\mathrm{Cu}$ と As の抽出率は逆に低くなった。これは, 溶媒中の $\mathrm{S}^{2-}$ イオンによって不溶塩である硫化物の形成によるものと 考えられる。しかし，いずれの場合も特に $\mathrm{Cu}$ の抽出率 が低く, 抽出溶媒には適さないといえる。

Fig. 2 から, 硫酸をはじめ塩酸, 硝酸なよ゙の無機酸 を溶媒として用いた場合， $\mathrm{Cu}, \mathrm{Cr}, \mathrm{As}$ のいずれの抽出 率も $80 \%$ 以上の高い值を示すが, これら以外の溶媒で はいずれかの抽出率が極端に低い值を示すことがわかる。 また, 抽出 TOC 量の値で比較すると硝酸を用いた場合 に高い值を示し, 塩酸, 硫酸を用いた場合は硝酸の場合 の半分程度の值となる。抽出する TOC は難分解性の有 機成分が大半を占め, この值が高ければ抽出処理後の溶 媒の処理がやっかいになるため, 抽出 TOC 量はできる 限り少ないことが望ましい。したがって, 抽出処理の溶 媒には塩酸あるいは硫酸が適切なあのとして選定される。 さらに, 硫酸は不揮発性の酸であるのに対し塩酸は揮発 性酸であるため, 溶媒の取扱いを考慮すれば最終的に不 揮発性である硫酸が適切であると判断できる。

\section{3 抽出温度選定のための回分実験（実験 2)}

実験 1 の結果から抽出溶媒には硫酸が適当であったた め, 実験 2 では実験 1 と同じ濃度の $0.25 \mathrm{~N}$ の硫酸を溶 媒として用いた。実験 2 で得られた抽出温度と $\mathrm{Cu}, \mathrm{Cr}$, As の抽出率との関係を Fig. 3 に示す。抽出温度が上が るにしたがって各々の抽出率が高くなり， $100^{\circ} \mathrm{C}$ での値 が最も高くなった。また, 四中には実験 1 でのオートク レーブを用いた場合 $\left(120^{\circ} \mathrm{C}, \quad 1 \mathrm{kgf} / \mathrm{cm}^{2}\right)$ の結果む参 考として載せている。実験 1 では, 抽出温度を $120^{\circ} \mathrm{C}$ ま で高めるために加圧しており，実験条件が異なるために 抽出温度の影響として実験 2 の結果と直接比較すること はできないものの, 実験 2 では抽出温度が $80 \sim 100^{\circ} \mathrm{C}$ の範囲では実験 1 の結果とほぼ同程度の值が得られた。 抽出温度を $100^{\circ} \mathrm{C}$ 以上にしょうとすれば, 抽出容器を加 圧する必要があり, 装置の構造が複雑になり, より多く のエネルギーが必要になることから，抽出温度は $100^{\circ} \mathrm{C}$

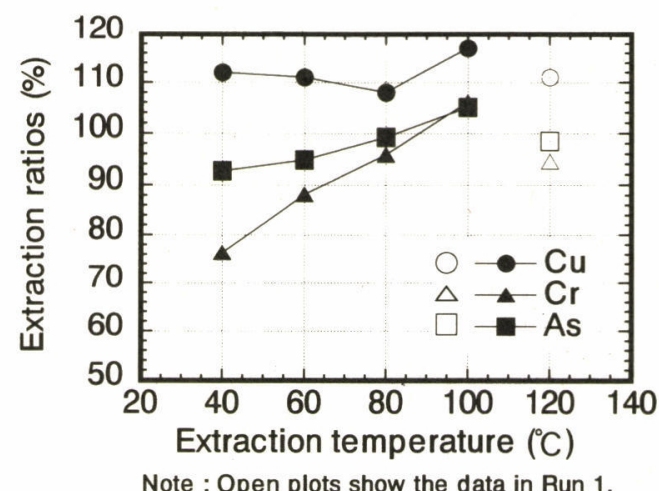

Fig. 3 Relationship between Extraction Temperature and Extraction Ratio 


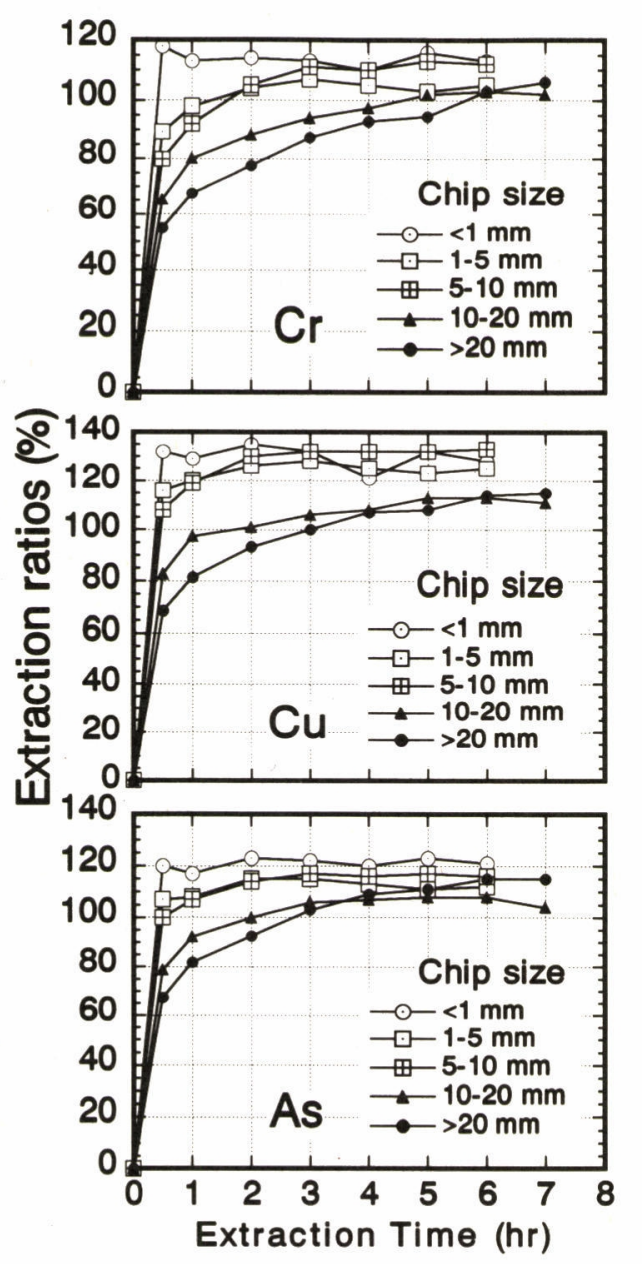

Note : $0.25 \mathrm{~N}$ sulfuric acid was used as a extractant.

Fig. 4 Changes of Extraction Ratios for Each Sample

以下に設定することが望ましいといえる。また， $80^{\circ} \mathrm{C}$ での抽出率の值よりも $100^{\circ} \mathrm{C}$ での值の方がやや高いこと から, 抽出温度は $100^{\circ} \mathrm{C}$ が適切であると判断できる。

\section{4 抽出時間と溶媒濃度の選定とチップ径の影響の把 握のための実験（実験 3 ）}

$0.25 \mathrm{~N}$ の硫酸を用いて各チップ径のサンプルを抽出 処理した場合の $\mathrm{Cu}, \mathrm{Cr}$, As の抽出率の経時变化を Fig. 4 に示し, 各濃度の硫酸を用いて $10 \sim 20 \mathrm{~mm}$ の チップを抽出処理した場合の $\mathrm{Cu}, \mathrm{Cr}, \mathrm{As} の$ 抽出率の 経時変化を Fig. 5 に示す。Fig. 4 および Fig. 5 のいず れの結果からあ，時間ととあに $\mathrm{Cu}, \mathrm{Cr}, \mathrm{As}$ 各々の抽 出率が増加し, $100 \%$ 近辺で飽和値に達する傾向がうか がえる。また, Fig. 4 からはチップの粒径が小さいほ ど短い時間で飽和値に達して抽出が完了することが読み

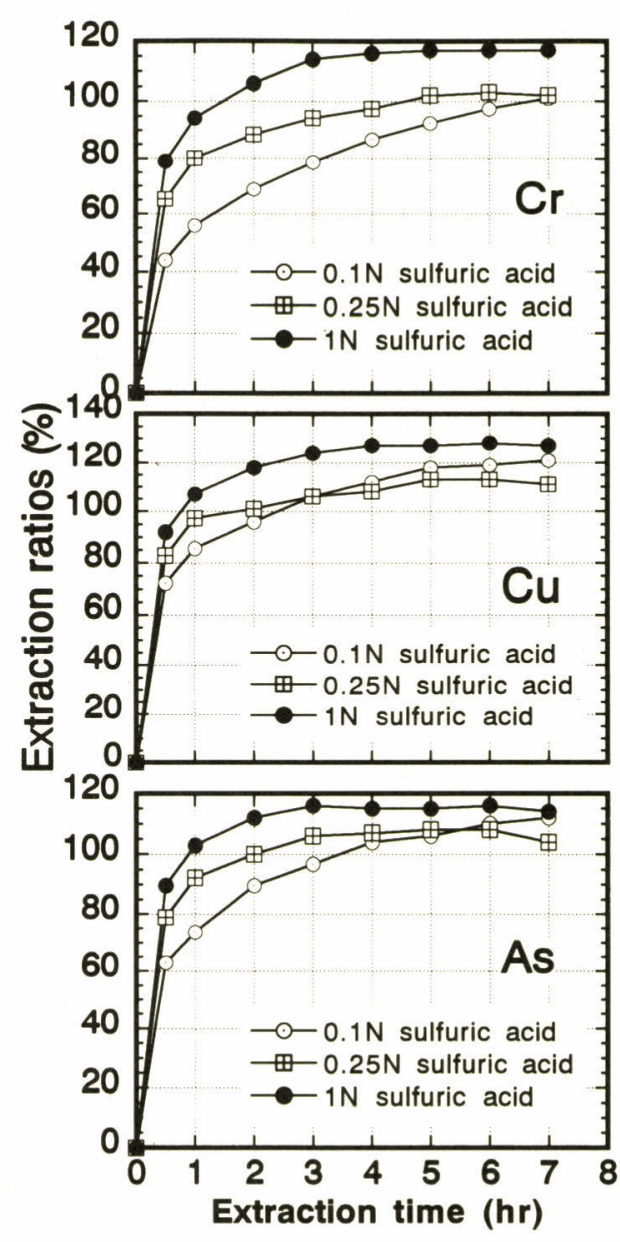

Note : Chip size was $10-20 \mathrm{~mm}$.

Fig. 5 Changes of Extraction Ratios with Each Sulfuric Acid

取れ，Fig. 5 からは硫酸の濃度が高いほど早く抽出さ れることがわかる。

Fig. 4 および Fig. 5 において, 抽出率が 100\% 以上 になる場合が多くみられるが，上述した実験時の種々の 誤差の影響に加えて, 溶媒のサンプリングによる固液比 の影響もこの原因の一つに数えられる。すなわち, 実験 中に溶媒を $20 \mathrm{cc}$ ずつ合計 7 回採水したため, 実験当初 $20 \mathrm{cc} ： 1 \mathrm{~g}$ であった固液比が $18.6 \mathrm{cc} ： 1 \mathrm{~g}$ まで段階的 に変化した。抽出率に及ぼす固液比の影響は今回検討し ていないが, 採水による実験中の固液比の変化はせいぜ い7\%であった。抽出処理効果の確認のため, 実験終了 後の木材チップ中の未抽出の $\mathrm{Cu}, \mathrm{Cr}, \mathrm{As}$ 量を分析し た結果, 抽出処理前の $\mathrm{Cu}, \mathrm{Cr}, \mathrm{As}$ 含有量の $5 \%$ 末満 であった。したがって，飽和値に達した段階で $\mathrm{Cu}, \mathrm{Cr}$, As 各々 95\% 以上の抽出率が得られたことになる。 
さらに, 実験 3 では抽出温度が $90 \sim 100^{\circ} \mathrm{C}$ であり約 $10^{\circ} \mathrm{C}$ の開きがあったことから, Fig. 3 の結果から判断 すれば, 実験 3 での抽出温度の值によって抽出率に $2.5 \sim 5 \%$ 程度の影響を及ぼしていることになる。

以上の要因を考慮して, 抽出率の飽和值との差が $3 \%$ 以内に達した時点までの抽出時間を「必要抽出時間」と 定義し, 木材チップの粒径別に, また溶媒である硫酸の 濃度ごとに必要抽出時間を表示することによって Fig. 6 が得られた。図からは, 木材チップが大きくなるにつ れて当然のことながら必要抽出時間は長くなり, 溶媒で ある硫酸の濃度が高いほど必要抽出時間は短くなる傾向 がうかがえる。また， 3 つの元素のうち，Cr の必要抽 出時間が他の 2 つの元素の值より大きい傾向があること から， 3っの元素の中では Cr が最む抽出しにくいこと がわかる。これはWarner ら ${ }^{8)}$ の実験からあ同様の結果 が得られており, 木材を CCA 薬剤で防腐・防蟻処理す る際に Cr が木材中のリグニンとかなり強固に結合して いるためであると推察されている。これに対して Cuは 木材中のセルロース成分と結合し, As は Cu あるいは $\mathrm{Cr}$ と酸性ひ酸銅 $\left(\mathrm{CuHAsO}_{4}\right)$ あるいはひ酸クロム $\left(\mathrm{CrAsO}_{4}\right)$ の形で木材中に存在していると考えられてお り, $\mathrm{Cr}$ の結合よりやや弱いために酸によって抽出され やすいものとみられる。通常木材をチップ化した場合, 長径が 10 ～ $20 \mathrm{~mm}$ の薄板状のチップが多く含まれる ことから， 10〜 $20 \mathrm{~mm}$ のサンプルに対する必要抽出時 間の值が実際に硫酸を用いて抽出除去する場合の 1 つの 目安になる。実験結果から判断すれば, $20 \mathrm{~mm}$ 以下の チップでは, $0.25 \mathrm{~N} \sim 1 \mathrm{~N}$ 程度の硫酸で約 5 時間抽出処 理を行うことで $95 \%$ 以上の $\mathrm{Cu}, \mathrm{Cr}, \mathrm{As}$ が除去できる ことがわかる。

10 ～ $20 \mathrm{~mm}$ の大きさのチップを抽出処理した場合の 単位チップあたりの抽出 TOC 量の経時変化を Fig. 7 に 示す。抽出時間が長くなるにつれて抽出 TOC 量む多く なり, 溶媒である硫酸濃度が高いほどその值む多くなる ことがわかる。Fig. 6 と Fig. 7 とをあわせて判断する 之, $1 \mathrm{~N}$ の硫酸を用いた場合の必要抽出時間は $0.25 \mathrm{~N}$ の硫酸の結果の約 $80 \%$ 程度であるが, 1.5 倍以上の TOC 量が同時に抽出されることがわかる。上述したよ うに, この TOC の成分はリグニンなどの難分解性有機 成分であり, 值が高いほど廃液の後処理が困難になるた め, 抽出 TOC 量はできるだけ低く抑えることが望まし い。したがって, 抽出装置の大きさや維持管理面に影響 する必要抽出時間と, 抽出廃液の処理との両面を考慮す れば, 硫酸濃度には適正な範囲が存在することが示唆さ れる。

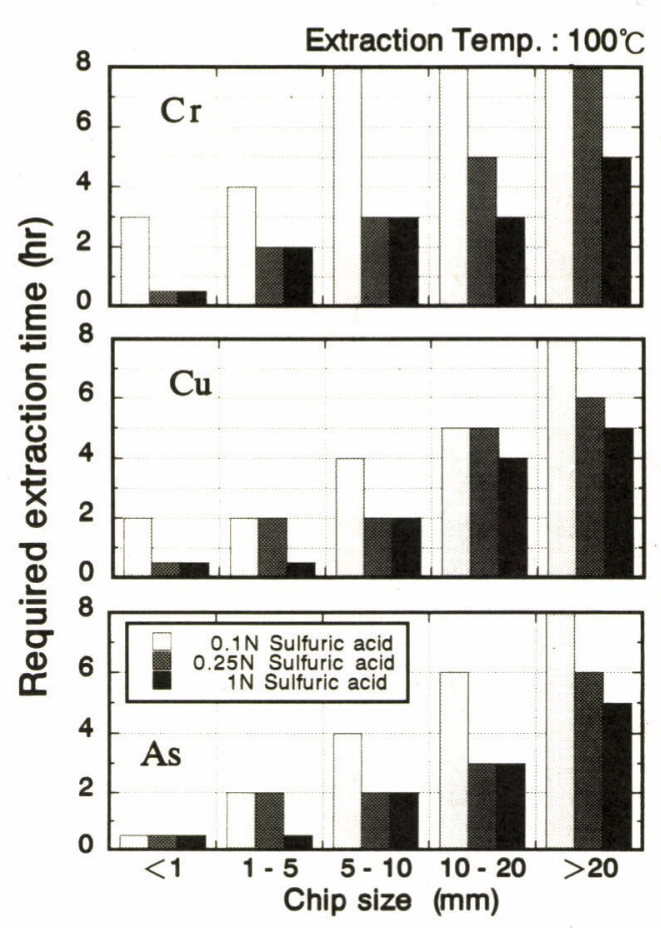

Fig. 6 Relationship between Chip Size and Required Extraction Time

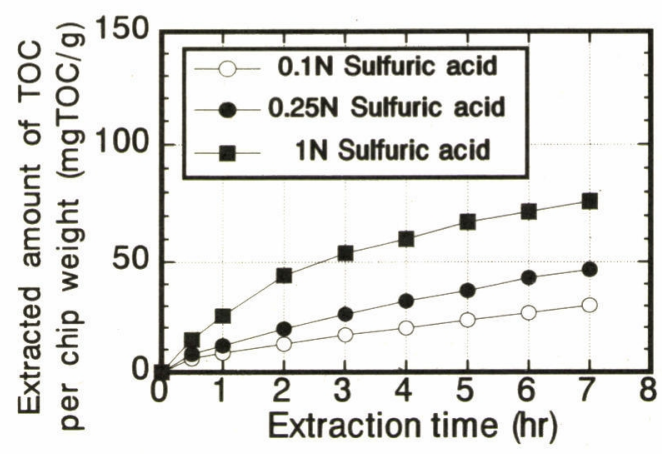

Fig. 7 Relationship between Extraction Time and Extracted Amount of TOC

\section{4. ま め}

CCA 防腐・防蟻処理木材から $\mathrm{Cu}, \mathrm{Cr}$ ，および As を 湿式で抽出除去する場合の基礎条件を得る目的で室内実 験を行った。その結果, 以下のような知見が得られた。

(1) $0.25 \mathrm{~N} \sim 1 \mathrm{~N}$ の硫酸を用いて $90 \sim 100^{\circ} \mathrm{C}$ で 5 時間 抽出処理することによって, $20 \mathrm{~mm}$ 以下の大きさの チップから含まれている $\mathrm{Cu}, \mathrm{Cr}$ ，および As の 95\% 以上を溶媒に抽出することができた。

(2) チップの大きさと必要な抽出時間, 同時に抽出され る有機性炭素量との関係として, Fig. 6, Fig. 7 を 
得ることができた。

(3) $\quad 0.1 \mathrm{~N} \sim 1 \mathrm{~N}$ の硫酸濃度の範囲では, 濃度が高いほ ど必要な抽出時間が短くなるが，その反面，微生物難 分解性成分が主体と考えられる有機性炭素の抽出量も 多くなることから, 硫酸濃度には適切な範囲が存在す ることが示唆された。

今後は, 本処理法の装置化の検討や, 抽出処理後の廃 液の処理あるいは抽出成分の再利用方法, 抽出処理後の チップの処分あるいは利用方法について検討し, 総合的 な観点から本処理法を評価することが必要と考えられる。

\section{「謝 辞」}

実験を行うにあたって，日本防腐木材工業組合お よび大阪市立環境科学研究所の関係者各位のご協力 をいただきました。ここに記して厚く感謝の意を表 します。

\section{考文献}

1） JIS-K 1556 ：クロム・銅・ひ素化合物系木材防腐鼡 (1985)
2) JIS-A 9107 : 加圧式クロム・銅・ひ素化合物系木材防 腐剂防腐処理木柱 (1986)

3 ）高月紘, 酒井伸一: 有害廃棄物, 中央法規, pp. 160 170 (1993)

4) 東レリサーチセンター：バーゼル条約と行政・企業の 対応, pp. 114-127 (1992)

5) 西谷隆司：CCA 処理木材の燃焼における七素の挙動と 捕捉に関する基礎実験, 第 33 回大気污染学会講演概要 集 (1992)

6 ）小林孝彰, 馬場建次：CCA 防腐剤で処理された木材の 燃焼にともなう七素の挙動, 環境科学会 1992 年年会講 演概要集 (1992)

7) E. スヨストローム: 木材化学 (基䃈と応用), 講談社, pp. $104-147$ (1983)

8 ) Warner, J.E. and Solomon, K. R. : Acidity As a Factor in Leaching of Copper, Chromium and Arsenic from CCA-Treated Dimension Lumber, Environ. Toxicl. \& Chem., Vol. 9, pp. 1331-1337 (1990) 


\title{
Extraction of Chrome, Copper, and Arsenic Compounds from Waste Preservative-Treated Wood
}

\author{
Yoshinori Kanjo *, Atsuko Kıмото ** and Atsuhiro Honda ${ }^{* * *}$ \\ * Osaka City University, Facl. of Engineering, Dept. of Civil Engineering, Research Associate \\ ${ }^{* *}$ Nihon Suido Consultant Co. Ltd. \\ *** Clean Japan Center \\ 'Correspondence should be addressed to Kanjo Yoshinori \\ ( 3-3-138 Sugimoto, Sumiyoshi-ku, Osaka 558 Jpan)
}

\begin{abstract}
Preservative-treated wood with chromated copper arsenate (CCA) has been used for 50 years in the world because of its reliability in preventing damage by insects or microorganisms. However, if this treated wood is waste and is incinerated, it will cause serious problems, in that incineration gas is discharged with high concentration of arsenic compounds, and the ash residue contains a lot of copper, chrome, and arsenic compounds.

In this paper, a series of extraction experiments was carried out to remove these hazardous materials from preservative-treated wood. Through the experiments, suitable conditions were obtained as follows;

1) suitable extractant is $0.25 \mathrm{~N}$ sulfuric acid.

2) suitable temperature ranges between $90{ }^{\circ} \mathrm{C}$ and $100{ }^{\circ} \mathrm{C}$.

Moreover, the relationships between extraction time, extracted amount of TOC, and wood tip size were obtained.
\end{abstract}

Key words : preservative-treated wood, extraction treatment, extraction ratio,

extracted amount of TOC 